\title{
WEE1 wt Allele
}

National Cancer Institute

\section{Source}

National Cancer Institute. WEE1 wt Allele. NCI Thesaurus. Code C92676.

Human WEE1 wild-type allele is located within 11p15.3-p15.1 and is approximately $16 \mathrm{~kb}$ in length. This allele, which encodes wee1-like protein kinase protein, is involved in the mediation of both protein phosphorylation and mitosis. Aberrant expression of the gene may be associated with glioblastoma. 